\title{
Study the performance of air-source heat pump assisted solar water heating system
}

\author{
Defeng Ding ${ }^{1}$, Wu Chen ${ }^{2 *}$ \\ (Fujian Province Key Laboratory of Naval Architecture and Ocean Engineering, JiMei University, \\ Xiamen 361021, China) \\ dingdefeng8866@163.com \\ ${ }^{*}$ Corresponding author
}

\begin{abstract}
Keywords: Air source heat pump, Solar, COP
Abstract. The paper studied the running characteristics of air-source heat pump assisted solar water heating system. The results showed that the temperature of hot water could reach $32{ }^{\circ} \mathrm{C}, 42{ }^{\circ} \mathrm{C}$ and $57{ }^{\circ} \mathrm{C}$ respectively, when the daily total radiation was $9.79 \mathrm{MJ} / \mathrm{m}^{2} 、 15.58 \mathrm{MJ} / \mathrm{m}^{2}$ and $21.42 \mathrm{MJ} / \mathrm{m}^{2}$. Under the radiation of $15.58 \mathrm{MJ} / \mathrm{m}^{2}$, heating $200 \mathrm{~L}$ water up to $55^{\circ} \mathrm{C}$, the power consumption of the system was $0.76 \mathrm{~kW} \cdot \mathrm{h}$ less than $0 \mathrm{MJ} / \mathrm{m}^{2}$, the coefficient of performance (COP) increased by $40 \%$. Compared to other auxiliary heat, the system consumed minimum power, the payback period of investment was about 4 years.
\end{abstract}

\section{Introduction}

Solar energy as a new kind of renewable clean energy, while the heat gained affected by weather conditions. Air source heat pump has good energy saving and efficiency, which can absorb the heat of surrounding environment.

Wang Ai-hui et al. ${ }^{[1]}$ analyzed the performance characteristics of a type partitioned heat storage tank used in solar air conditioning, the results showed that the partitioned tank using in solar air conditioning system can improve the property of the system. Based on the measured meteorological data in Chongqing area, Ding Yong et al. ${ }^{[2]}$ analyzed the performance and the key influence factors of the air-source heat pump assisted solar hot water system. Poppi et al. ${ }^{[3]}$ defined and modeled an air source heat pump combisystem based on products available on the market, the results showed that variations in electricity price affected the additional investment limit far more than the other economic parameters. Nogueira et al. ${ }^{[4]}$ presented a complete development of software for sizing small solar water heating systems, developed an application framework and structured an algorithm to minimize the user intervention.

Xiamen belongs to China's solar energy rich district, the research shows that the solar water heater in the area has certain application potential ${ }^{[5]}$. During the whole year, solar energy is abundant in summer, while the maximum hot water load is in winter. Based on this, it is necessary to study the operating characteristics, the economic performance of the air source heat pump auxiliary solar hot water system in autumn and winter.

\section{Experimental rig}

The air source heat pump auxiliary solar hot water system is shown in Fig. 1. The system consists of solar collector unit, heat pump auxiliary heating unit, data acquisition control unit. The platform consists of $4 \mathrm{~m}^{2}$ blue titanium plate collectors, solar circulating pump of $550 \mathrm{~W}$, Mitsubishi compressor of RB247GHAC, rated $1030 \mathrm{~W}$, a circulating water tank with capacity of $200 \mathrm{~L}$. Solar power meter of TES-133 3R was used to test the power of the solar radiation, PT100 resistances were used to measure the temperature of the plate collector. The Huba pressure sensors measured the suction pressure and discharge pressure of the compressor. During experiment, the data of temperature, pressure were collected by Agilent 34972a multi-channel data acquisition instrument. 


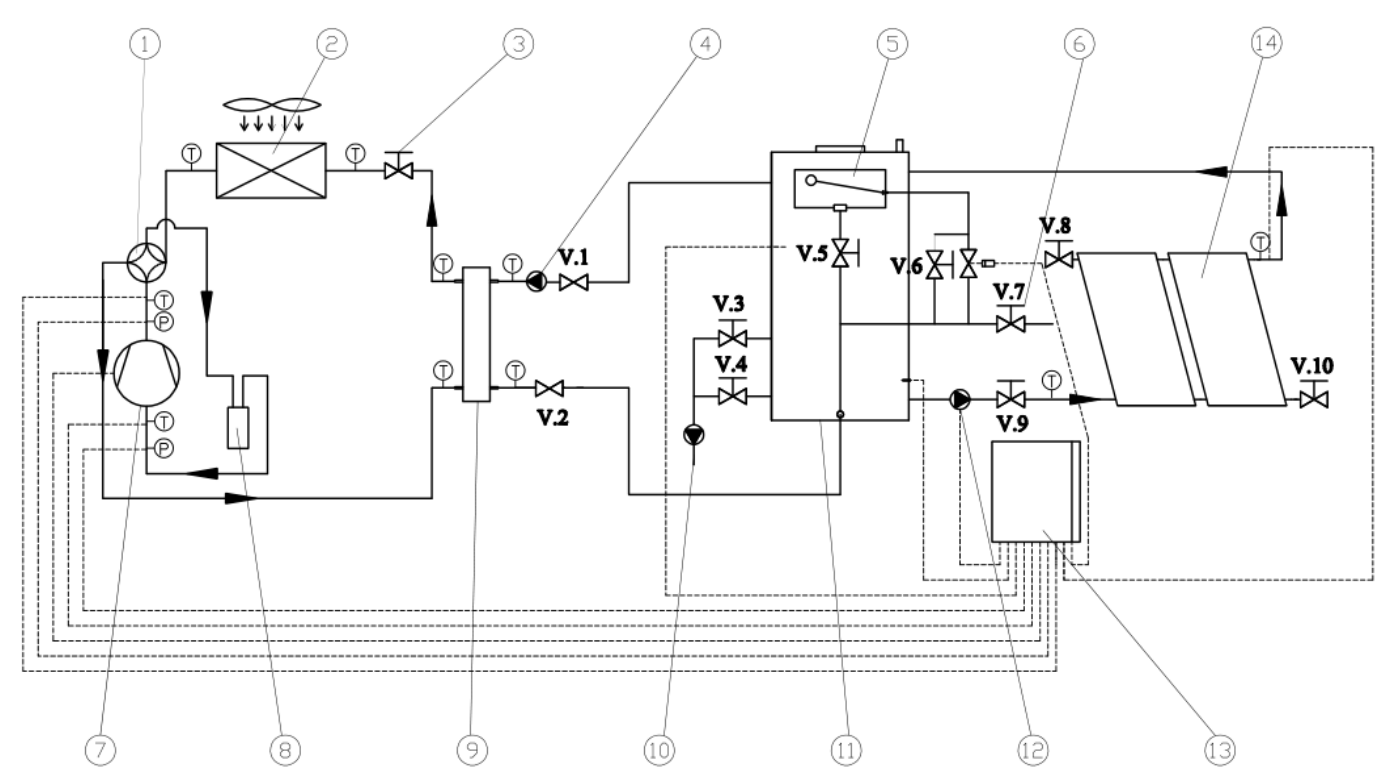

1-Four-way valve; 2- Evaporator; 3- Expansion valve; 4- Circulating pump of heat pump; 5- Expansion tank of inlet water; 6Inlet pipe; 7- Compressor; 8- Reservoir; 9- Tube-in-tube condenser; 10-Outlet pipe; 11- Recirculating water tank; 12 Circulating pump of solar; 13-Control cabinet; 14- Flat-plat solar collector; T- Temperature sensor; P- Pressure sensor; V-Valve Fig.1 Schematic diagram of the air-source heat pump assisted solar water heating system

\subsection{Experimental procedure}

A programmable logic controller (PLC) was adopted to control the process of the system. Reference national standards, the initial temperature of hot water was set $15{ }^{\circ} \mathrm{C}$. Solar energy started being collected at $8 \mathrm{am}$, and the system could operate in two modes: air source assisted solar hot water mode and air source heat pump water mode. When the solar radiation was strong enough, if the temperature difference of the import and export temperature sensor was greater than $8{ }^{\circ} \mathrm{C}$, the solar circulating pump will be started and running for 5 minutes. The hot water in the solar panels will be pumped into the circulating water tank. If the temperature of the circulating water tank had reached $55{ }^{\circ} \mathrm{C}$ at $4: 30$ $\mathrm{pm}$, the air source heat pump unit wouldn't be started. When the solar radiation was weak, the temperature of the circulating water tank had not reached $55{ }^{\circ} \mathrm{C}$, the air source heat pump unit would be started and heated the water in the tank until $55{ }^{\circ} \mathrm{C}$.

\subsection{Evaluation index}

The heat transfer power on the condenser side:

$$
W_{s y s}=\mathrm{c}_{\mathrm{w}} m_{\mathrm{w}}\left(T_{t_{2}}-T_{t_{1}}\right) /\left(t_{2}-t_{1}\right)
$$

Where, $W_{\text {sys }}$ is the power of heat exchanging under solar hot water model, $c \mathrm{w}$ is the specific heat of water, $m \mathrm{w}$ is the quality of the water, $T_{\mathrm{t} 2}$ is the temperature of hot water at the time of $t_{2} 、 T_{\mathrm{t} 1}$ is the temperature of hot water at the time of $t_{1}$.

Compression ratio PR is defined as follow:

$$
P R=P_{\text {dis }} / P_{\text {suc }}
$$

Where $P_{\text {dis }}$ is the discharge pressure of the compressor, $P_{\text {suc }}$ is the suction pressure of compressor. The coefficient of performance under solar hot water model ${ }^{[6]}$ :

$$
\mathrm{COP}=c_{\mathrm{w}} m_{\mathrm{w}}\left(T_{t+\tau}-T_{t}\right) / \int_{t}^{t+\tau} P_{c}(\tau) d \tau
$$

Where, $P_{\mathrm{c}}$ is the power consumption of heat pump, $T_{\mathrm{t}+\tau}$ is the terminate temperature of circulating water tank, $T_{\mathrm{t}}$ is the initial temperature of circulating water tank. 


$$
T_{t}=\sum_{i=1}^{n} T_{i} / n
$$

Where, $n$ is the number of measurement points in the water tank, $T_{\mathrm{i}}$ is the temperature of NO $i$ measurement point at the time of $t$.

\section{Experimental results and analysis}

The performance of air-source heat pump assisted solar water heating system in Xiamen's autumn and winter was studied as follow.

As shown in Fig.2, the radiation rate increased first and then reduced on typical day. During the operation of the system, the sun radiation increased since 8am, the most radiant was during 11:00 to 13:30 (about $960 \mathrm{~W} / \mathrm{m}^{2}$ ). The temperature of water elevated with the radiating just before $2 \mathrm{pm}$. After that, the increasing of heat dissipating made the temperature of water reduced with the radiating. The water temperature stabilized at $42{ }^{\circ} \mathrm{C}$ eventually, the air-source heat pump will activated automatically and heated the water until $55^{\circ} \mathrm{C}$.

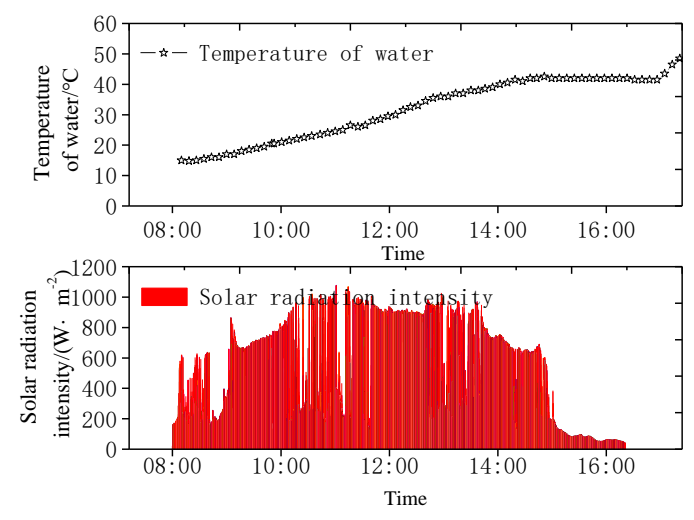

Fig.2 Changes of solar radiation intensity and water temperature on typical day

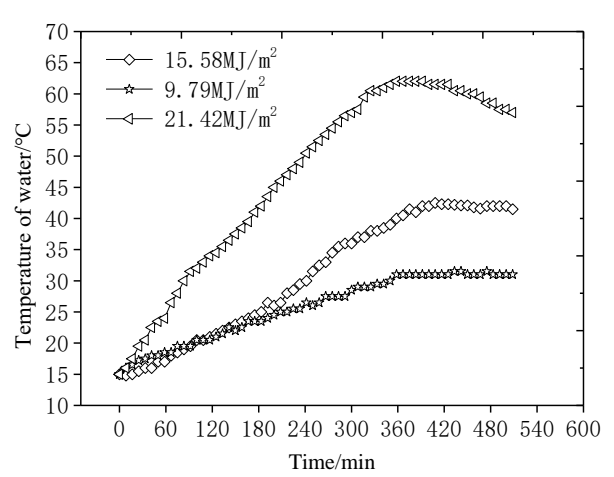

Fig.3 Effect of daily total solar radiation on the temperature of water

Figure 3 shows the change of hot water's temperature with solar irradiation in the autumn and winter of Xiamen. The solar radiation was $9.79 \mathrm{MJ} / \mathrm{m}^{2} 、 15.58 \mathrm{MJ} / \mathrm{m}^{2}$ and $21.42 \mathrm{MJ} / \mathrm{m}^{2}$ respectively. The temperature of water were increased when the solar irradiation were elevated. The temperature could reach $62{ }^{\circ} \mathrm{C}$ when the solar radiation was $21.42 \mathrm{MJ} / \mathrm{m}^{2}$; while heated water to $32{ }^{\circ} \mathrm{C}$ and $42{ }^{\circ} \mathrm{C}$ respectively at the radiation of $9.79 \mathrm{MJ} / \mathrm{m}^{2}$ and $15.58 \mathrm{MJ} / \mathrm{m}^{2}$.

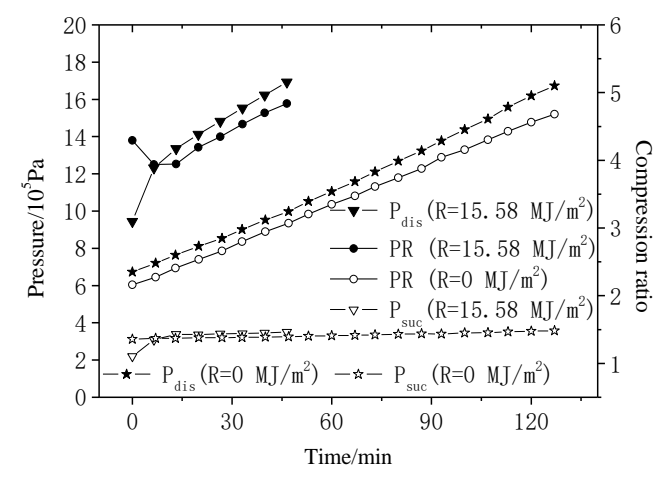

Fig.4 Suction press, discharge press and compression ratio variation with time

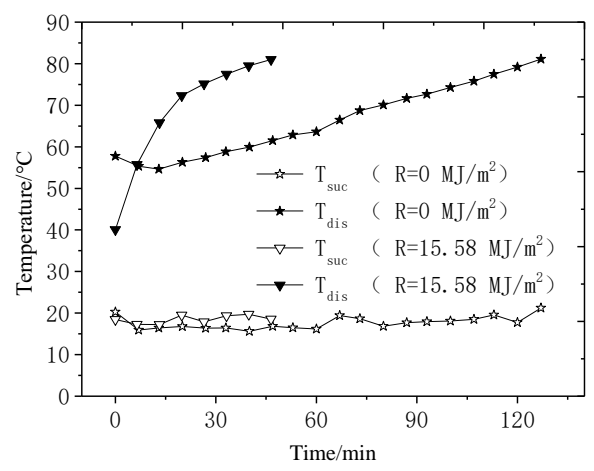

Fig.5 Suction temperature and discharge temperature variation with time

Due to the instability of solar radiation, it's necessary to compare the operating characteristics in sunny and rainy days. The variation of compression ratio, the discharge pressure and suction pressure with time were shown in Fig. 4. From the figure, the temperature of hot water could reach $42{ }^{\circ} \mathrm{C}$ at 16:30. On this basis, the air source auxiliary heat pump used shorter time to heat the water to $55^{\circ} \mathrm{C}$. In rainy weather, because the solar radiation was almost $0 \mathrm{MJ} / \mathrm{m}^{2}$, the air source heat pump need run 127 
$\min$. The compression ratio and the exhaust pressure were increased with time. When the temperature of water was $55{ }^{\circ} \mathrm{C}$, the compression ratio was 4.8 , the exhaust pressure was $17 \times 10^{5} \mathrm{~Pa}$. In rainy weather, water was heated by air source auxiliary heat pump completely. The heat pump could perform steadily. The compression ratio rose to 4.7 from 2.2 with the water temperature rose to $55{ }^{\circ} \mathrm{C}$ from $15{ }^{\circ} \mathrm{C}$. When the solar radiation was $15.58 \mathrm{MJ} / \mathrm{m}^{2}$, the suction pressure was slightly higher than $0 \mathrm{MJ} / \mathrm{m}^{2}$. The average exhaust pressure had reached $2.6 \times 10^{5} \mathrm{~Pa}$.

Fig.5 gives the variation of suction temperature and discharge temperature with time. When the solar radiation was $15.58 \mathrm{MJ} / \mathrm{m}^{2}$, the exhaust temperature of compressor increased rapidly in the early stage of system operation. In the first 6 minutes, the temperature rose from $40{ }^{\circ} \mathrm{C}$ to $55.8{ }^{\circ} \mathrm{C}$ fleetly. The evaporator absorbed heat from the air continuously and the exhaust temperature of the compressor increased gradually. When the solar radiation was $15.58 \mathrm{MJ} / \mathrm{m}^{2}$, the suction temperature was slightly higher than $0 \mathrm{MJ} / \mathrm{m}^{2}$.

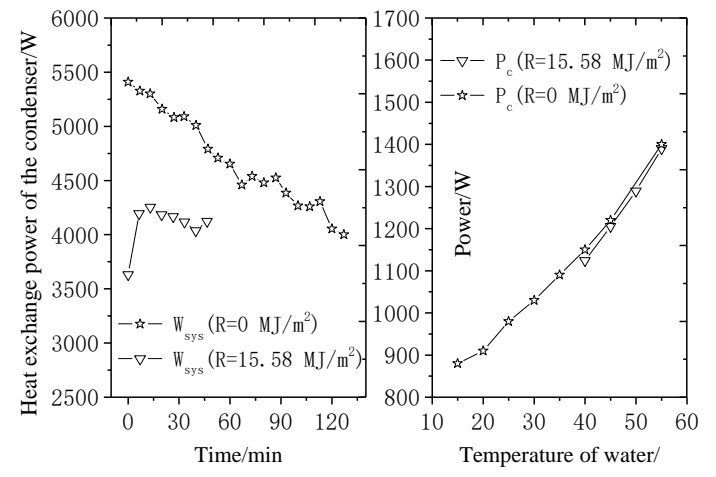

Fig.6 Variations of power consumption and heat exchange power of the condenser with time

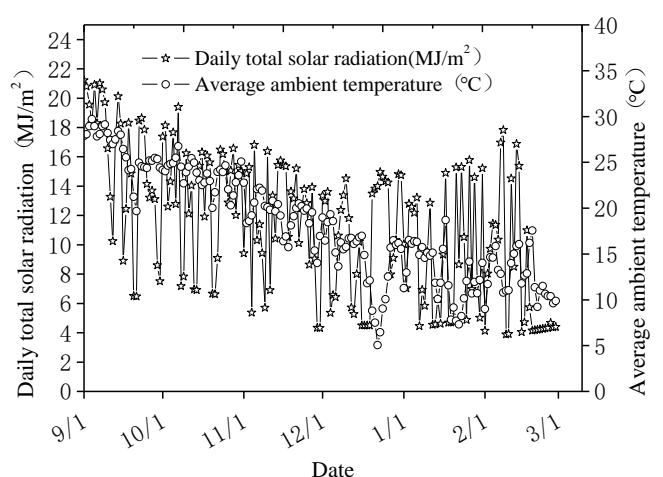

Fig.7 Daily total solar radiation and average ambient temperature in autumn and winter of Xiamen

As shown in the Fig.6, the power consumption increased with the increasing of water temperature. At the same time, the exchanging heat of hot water on the condenser side decreased with the operation of the air source heat pump gradually. This reflected a gradual reduction in the temperature difference between the hot water and the condensing refrigerant. When the solar radiation was 15.58 $\mathrm{MJ} / \mathrm{m}^{2}$, the average exchange consumption was $4087 \mathrm{~W}$, which was $14.7 \%$ less than the radiation of $0 \mathrm{MJ} / \mathrm{m}^{2}$. The power consumption was $15.7 \%$ more than rainy day.

Table 1 gives the results under different meteorological conditions. Under the same ambient temperature and relative humidity, the system heated $200 \mathrm{~L}$ water from $15{ }^{\circ} \mathrm{C}$ to $55{ }^{\circ} \mathrm{C}$ need 1.92 $\mathrm{kW} \cdot \mathrm{h}$ electricity, which was $0.76 \mathrm{~kW} \cdot \mathrm{h}$ less than $0 \mathrm{MJ} / \mathrm{m}^{2}$. The coefficient of performance was 4.9 , higher than $0 \mathrm{MJ} / \mathrm{m}^{2}$.

Table 1 Comparison under different meteorological conditions

\begin{tabular}{cccccc}
\hline $\begin{array}{c}\text { Radiation } \\
{\left[\mathrm{MJ} \cdot \mathrm{m}^{-2}\right]}\end{array}$ & $\begin{array}{c}\text { Environment } \\
\text { temperature }\left[{ }^{\circ} \mathrm{C}\right]\end{array}$ & $\begin{array}{c}\text { Relative humidity } \\
{[\%]}\end{array}$ & Heat gained $[\mathrm{MJ}]$ & $\begin{array}{c}\text { Power consumption } \\
{[\mathrm{kW} \cdot \mathrm{h}]}\end{array}$ & COP \\
\hline 15.58 & 25.8 & $57 \%$ & 22.68 & 1.92 & 4.9 \\
0 & 24.1 & $51 \%$ & 0 & 2.68 & 3.5 \\
\hline
\end{tabular}

\section{Economic analysis}

According to the upper analysis, the average collector efficiency of the collectors was 0.4. Meteorological data for building thermal environment analysis in Xiamen city is introduced in this paper, both the daily total solar radiation and average ambient temperature in autumn and winter of Xiamen were shown in Fig.7. It can be seen from the figure that the total daily radiation in a month fluctuates greatly, it ranges from $6 \mathrm{MJ} / \mathrm{m}^{2}$ to $16 \mathrm{MJ} / \mathrm{m}^{2}$. The average ambient temperature decreased in autumn and tend to be stable in winter. For the system, the average collected heat during the two seasons is $2066 \mathrm{MJ} / \mathrm{m}^{2}$. Nowadays, electric heating and air source heat pump are the most common auxiliary heating of solar energy. According to relevant literatures ${ }^{[7]}$, the price of electricity is 0.1417 
yuan per MJ, the daily water consumption of a family of four is about $200 \mathrm{~L}$. The initial investment and operation cost of four hot water devices was analysed. Table 2 shows that the air-source heat pump assisted solar water heating system need the highest initial investment, but the lowest running cost. The power consumption is $30 \%$ of the solar water heater with auxiliary electrical heating and $45 \%$ of the air source heat pump heater in autumn and winter. The recovery period of investment is about 4 years.

\section{Conclusions}

The operation characteristics of the air source heat pump auxiliary solar hot water system in Xiamen city was analyzed in this paper.

1) At the beginning, the water temperature increased with the solar radiating gradually. Due to the leakage of heat, when the radiation no longer enhance, the water was difficult to absorb solar energy.

2) The solar energy efficiency of the system was about 0.4 , and the temperature of water could reach $32{ }^{\circ} \mathrm{C}, 42{ }^{\circ} \mathrm{C}, 57{ }^{\circ} \mathrm{C}$ when the radiation were $9.79 \mathrm{MJ} / \mathrm{m}^{2}, 15.58 \mathrm{MJ} / \mathrm{m}^{2}$ and $21.42 \mathrm{MJ} / \mathrm{m}^{2}$.

3) The power consumption under the radiation of $15.58 \mathrm{MJ} / \mathrm{m}^{2}$ was $0.76 \mathrm{~kW} \cdot \mathrm{h}$ less than $0 \mathrm{MJ} / \mathrm{m}^{2}$, while the coefficient of performance had increased by $40 \%$.

4) For air-source heat pump assisted solar water heating system, the recovery period of investment was about 4 years.

\section{Acknowledgement}

This research was financially supported by Fujian Science and Technology Key Projects Fund (Grant NO. 2014H0035).

\section{References}

[1] A. H. Wang, S. M. Jin. Study on the Performance Charcteristics of the Partitioned Tank Using in the Solar Air Conditioning. Fluid Machinery, vol. 40, pp. 68-72, 2012.

[2] Y. Ding, Y. Liu. Analysis of key factors at air -source heat pump assisted solar hot water system in Chongqing area. Acta Energiae Solaris Sinica, vol. 36, pp. 2402-2410, 2015.

[3] P. Stefano, B. Chris, H. Andreas, et al. Analysis of system improvements in solar thermal and air source heat pump combisystems. Applied Energy, vol. 173:606-623, 2016.

[4] C. E. C. Nogueira, M. L. Vidotto, F .Toniazzo, et al. Software for designing solar water heating systems. Renewable \& Sustainable Energy Reviews,2016,58:361-375.

[5] R. C. Zheng. Technical guidebook for solar water heating system of civil buildings. Chemical Industry Press, pp. 24-26, 2011.

[6] K. Bakirci, O. Ozyurt, K. Comakli, et al. Energy analysis of a solar-ground source heat pump system with vertical closed-loop for heating applications. Energy, vol. 36, pp. 3224-3232, 2011.

[7] S. H. Li, W. B. Wu, X. S. Zhang, et al. Experimental study and application analysis on solar-assisted heat pump water heater device. Journal of Southeast University, vol. 35, pp. 82-85, 2005. 